\title{
Emodin inhibits the proliferation and migration of B16F10 cells and induces their apoptosis
}

\author{
Mingjie Yuan", Liang Chen", Wanchen Wang, Dengke Qin, Chuanlong Jia, Chi Liu, Heng Wang, \\ Jingjing Zhu, Yu Guo, Yiqun Zhou, Ping Yang, Haiguang Zhao, Tianyi Liu, Bo Bi \\ Shanghai Key Laboratory of Clinical Geriatric Medicine, Fudan University Affiliated Hua Dong Hospital, Shanghai, China \\ Contributions: (I) Conception and design: M Yuan, L Chen; (II) Administrative support: J Zhu, Y Guo, Y Zhou, P Yang, H Zhao, T Liu, B Bi; \\ (III) Provision of study materials or patients: W Wang, D Qin, C Jia; (IV) Collection and assembly of data: C Liu, H Wang; (V) Data analysis and \\ interpretation: M Yuan, L Chen; (VI) Manuscript writing: All authors; (VII) Final approval of manuscript: All authors. \\ \#These authors contributed equally to this work. \\ Correspondence to: Prof. Tianyi Liu; Prof. Bo Bi. Fudan University Affiliated Hua Dong Hospital, 221 Yanan West Road, Jingan, Shanghai 200040, \\ China. Email: tianyiliucn@126.com; yuranliu@126.com.
}

\begin{abstract}
Background: Emodin, extracted from the rhizomes of various Chinese herbs, is a natural anthraquinone derivative with the formula $\mathrm{C} 15 \mathrm{H} 10 \mathrm{O} 5$. Many recent studies have shown that emodin has an antitumour effect. In this study, emodin was investigated in vitro to observe its effect on the proliferation, migration, and apoptosis of the B16F10 melanoma cell line.
\end{abstract}

Methods: B16F10 cells were treated with 20, 40, 60, or $80 \mu \mathrm{M}$ emodin for 24 h. A Cell Counting Kit- 8 (CCK-8) was used to measure the effect of emodin on cell proliferation. After $24 \mathrm{~h}$ of emodin treatment, a scratch test was used to detect the wound healing rate of each group. A Transwell test was used to measure the effect of emodin on cell migration ability. The apoptosis rate of the B16F10 cells was determined by a TUNEL assay. The expression of caspase- 3 was measured by western blot analysis.

Results: Compared with the control group, emodin significantly inhibited the proliferation and migration of the B16F10 cells in a concentration-dependent manner. Emodin also inhibited the migration of the B16F10 cells and induced their apoptosis.

Conclusions: Emodin can effectively suppress the viability and migration of B16F10 cells and may induce apoptosis through the mitochondrial pathway or death receptor-mediated pathway.

Keywords: Emodin; B16F10; proliferation; migration; apoptosis

Submitted Feb 15, 2020. Accepted for publication Sep 03, 2020.

doi: $10.21037 /$ tcr-20-1040

View this article at: http://dx.doi.org/10.21037/tcr-20-1040

\section{Introduction}

Cutaneous melanoma (CM) is a skin tumour derived from abnormal melanocytes that is prone to migrate in the early stage. It accounts for approximately $75 \%$ of skin cancerrelated deaths (1). Recently, the incidence of CM is one of the most rapidly increasing among cancers worldwide. The increased incidence varies among populations, ranging from $3 \%$ to $7 \%$ (2). Studies from Europe and the United States reports increases in the incidence of $\mathrm{CM}(3,4)$.

The mortality of melanoma has also increased in men older than 65 years. This finding may be attributed to their unique biology and/or an altered host immune response (5). Previously, treatment options were limited by modest response rates in patients with advanced-stage melanoma. Despite targeted therapy and immunotherapy raising the response rate in recent years, the long-term survival rate remains low. Therefore, the discovery of efficient therapeutics will be key for treating CM to improve overall survival.

Emodin, extracted from the rhizomes of various Chinese herbal medicines, such as rhubarb, rheum and 
polygonum, is a natural anthraquinone derivative with the formula $\mathrm{C}_{15} \mathrm{H}_{10} \mathrm{O}_{5}$. The chemical name of emodin is 1,3,8-trihydroxyanthraquinone. It forms an orange-yellow long needle-like crystal. In recent years, many studies have confirmed that emodin has many biological effects, such as anti-inflammatory, antibacterial, and immune regulation effects (6-8). With further research on its antitumour activity, emodin was found to inhibit lung cancer, breast cancer and other tumours by inhibiting tumour cell proliferation and promoting apoptosis $(9,10)$.

This study mainly investigated the effect of emodin on the proliferation, migration, and apoptosis of the $\mathrm{B} 16 \mathrm{~F} 10$ mouse melanoma cell line. The goal was to further understand the mechanism of apoptosis and provide experimental evidence for the treatment of melanoma with emodin.

\section{Methods}

\section{Materials}

Emodin and dimethyl sulfoxide (DMSO) were purchased from Sigma. DMEM, foetal bovine serum, a CCK-8 kit, and $0.25 \%$ EDTA-trypsin were purchased from Gibco (Thermo Fisher Scientific, Inc). A TUNEL kit and DAPI staining kit were purchased from Nanjing Kaiji Biotechnology Co., Ltd.; a penicillin and streptomycin solution were purchased from United Bioresearch, Inc. Sixwell cell plates and 96-well cell plates were purchased from Shanghai Jiayuan Biotech Co., Ltd. The polyvinylidene fluoride (PVDF) membranes were purchased from Beijing Solarbio Science \& Technology Co., Ltd. The antibodies against $\beta$-actin (rabbit anti-mouse RRID: AB_2242334) and caspase-3 (RRID: AB_331439) were purchased from Cell Signalling Technology, Inc. The secondary fluorescence antibody (polyclonal goat anti-rabbit RRID: AB_2801422) was purchased from Yeasen Biotech Co., Ltd.

\section{Cell line and cell culture}

Mouse melanoma B16F10 cells (RRID: CVCL_0159) were purchased from the Cell Bank of the Chinese Academy of Sciences. B16F10 cells were grown in DMEM $(\mathrm{pH}=7.4)$ with $10 \%$ foetal bovine serum and penicillin (final concentration, $100 \mathrm{U} / \mathrm{L}$ ) and streptomycin (final concentration, $100 \mathrm{mg} / \mathrm{L}$ ). The cells were cultured in an incubator with $95 \%$ air and $5 \% \mathrm{CO}_{2}$ with saturated humidity at $37^{\circ} \mathrm{C}$. The cells in the logarithmic growth phase were selected for experiments and digested with
EDTA-trypsin when their confluence reached $80-90 \%$. The cells were seeded into six $96-$ well plates. The medium was changed every 2 days.

\section{Preparation of emodin}

Emodin was dissolved in DMSO at a concentration of $0.2 \mathrm{mmol} / \mathrm{L}$ as a stock solution and stored in a refrigerator at $-20{ }^{\circ} \mathrm{C}$. The stock solution was diluted to a desired concentration in DMEM medium at the time of use. The mass fraction of DMSO in the emodin solution was less than $0.1 \%$.

\section{Cell proliferation assay}

The cells in the logarithmic growth phase were washed twice with PBS, and $0.25 \%$ trypsin was used to detach the cells at room temperature, and the cells was transferred to a centrifuge tube. After resuspending the cells, the cells were counted by a haemocytometer under the microscope and seeded into a 96-well plate at $10^{4}$ cells/well. The seeded cells were cultured for $24 \mathrm{~h}$. The $0.1 \%$ DMSO group was simultaneously prepared as a control, and the experimental group was treated with $20,40,60$, or $80 \mu \mathrm{M}$ emodin for $24 \mathrm{~h}$. The blank zero group was treated with equal amounts of PBS. After adding $10 \mu \mathrm{L}$ of CCK- 8 reagent to each well, the cells were incubated for $4 \mathrm{~h}$ in an incubator. The absorbance was measured at a wavelength of $450 \mathrm{~nm}$, and the viability of the $\mathrm{B} 16 \mathrm{~F} 10$ cells in different concentrations of emodin was calculated.

\section{Cell scratch test}

The cells in the logarithmic growth phase were added to 6-well plates. Three parallel lines were drawn as a marker underneath the 6-well plate. When the confluence reached $100 \%$, a $100 \mu \mathrm{L}$ pipette tip was used to place a scratch vertically and slowly into the 6-well plate. The wells were washed with PBS three times, and serum-free medium with $20,40,60$, and $80 \mu M$ emodin was added. Serum-free (0.1\% DMSO) medium was simultaneously added to a well as the control. The cells were observed under an inverted microscope at $0 \mathrm{~h}$ and $24 \mathrm{~h}$, and ImageJ (RRID:SCR_003070) was used to calculate the migration rate.

\section{Transwell test}

Cells in the logarithmic growth phase were added to the 
upper chamber at a density of $2 \times 10^{5} / \mathrm{mL}(150 \mu \mathrm{L})$ and treated with $20,40,60$, or $80 \mu \mathrm{M}$ emodin in serum-free medium for $24 \mathrm{~h}$. The control group was treated with $0.1 \%$ DMSO. Then, $800 \mu \mathrm{L}$ of medium containing $10 \%$ foetal bovine serum was added to a 24 -well plate placed in the lower chamber. The 24-well plate was placed in an incubator for $24 \mathrm{~h}$. The upper chamber liquid was blotted and carefully wiped with a cotton swab after $24 \mathrm{~h}$. The cells on the surface of the upper chamber were removed, and the bottom surface was fixed with $4 \%$ paraformaldehyde and stained with crystal violet for $20 \mathrm{~min}$. The number of migrating cells was counted in different fields of view under a microscope. Five visual fields were randomly selected for statistical analysis, and the differences between the groups were statistically analysed.

\section{TUNEL assay}

Cell slides were washed with deionized water and sterilized for use. B16F10 cells were seeded onto 6-well plates at a density of $2 \times 10^{5} /$ well and cultured overnight. After the cells were attached, emodin $(60 \mu \mathrm{M})$ was added, and incubation was continued for $24 \mathrm{~h}$. The cells attached to the cell slides were naturally dried and fixed with $4 \%$ paraformaldehyde for $30 \mathrm{~min}$ and washed with PBS 3 times. The TUNEL reaction solution was prepared according to the instructions, and the whole process was performed on ice. The reaction solution was added dropwise to each cell slide to allow the reaction solution to completely cover the cell area. The reaction was incubated at $37^{\circ} \mathrm{C}$ for $1 \mathrm{~h}$ in the dark and washed 3 times with PBS for $5 \mathrm{~min}$ each time. The DAPI solution was diluted to $1 \mathrm{mg} / \mathrm{L}$ and then added dropwise to the cell slide. The cells were then incubated at $37^{\circ} \mathrm{C}$ for $15 \mathrm{~min}$ in the dark and then washed 3 times with PBS for 5 min each time. The image was observed under an inverted fluorescence microscope after a quenching agent was added, and the surrounding area was devoid of cells. Three fields of view were randomly selected and photographed under a laser confocal microscope.

\section{Western blot analysis}

Proteins were collected and separated through SDSpolyacrylamide gel electrophoresis from cells that had reached $80-90 \%$ confluence and treated with 20,40 and $60 \mu \mathrm{M}$ emodin for $24 \mathrm{~h}$. The control group was treated identically. The separated proteins were transferred to a

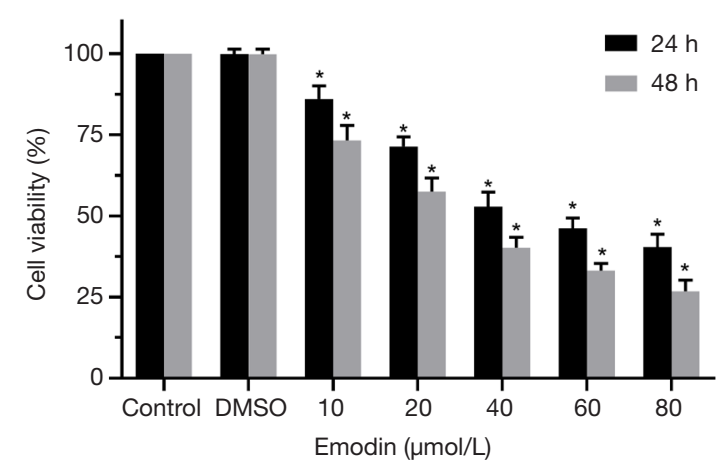

Figure 1 Effect of emodin on the proliferation of the B16F10 cells. There was no significant difference in the proliferation rate between the $0.1 \%$ DMSO group and the control group. Cells treated with different concentrations of emodin showed an inhibitory effect on the proliferation of the B16F10 cells compared with the control group $\left({ }^{*}, \mathrm{P}<0.05\right)$.

PVDF membrane with the application of $90 \mathrm{~V}$ and 200 $\mathrm{mA}$ for $60 \mathrm{~min}$. Next, PVDF membranes were incubated overnight in a diluted antibody solution (rabbit anti-mouse caspase- 3 and anti- $\beta$-actin; $1: 3,000)$ at $4{ }^{\circ} \mathrm{C}$. The blots were then incubated with the secondary antibody $(1: 3,000)$ for $1 \mathrm{~h}$ at $37^{\circ} \mathrm{C}$. The results were detected using an Odyssey infrared imaging system.

\section{Statistics}

After all the experiments were repeated 3 times, the measurement data were expressed as the means \pm standard deviation $(X \pm S D)$, and the data were processed by SPSS 19.0 statistical software (RRID:SCR_002865). The two groups were compared by $t$-test, and $\mathrm{P}<0.05$ was used to indicate a statistically significant difference.

\section{Results}

\section{Effect of emodin on the proliferation of the B16F10 cells}

B16F10 cells were treated with different concentrations of emodin $(20,40,60,80 \mu \mathrm{M})$ for $24 \mathrm{~h}$ and $48 \mathrm{~h}$, and the viability of the B16F10 cells showed a decreasing trend. There was a significant difference compared with the control group $(\mathrm{P}<0.05)$ (Figure 1$)$. As the emodin concentration increased, the cell viability rate decreased, showing that emodin inhibited the proliferation of B16F10 cells in a concentration-dependent manner. Changes in 

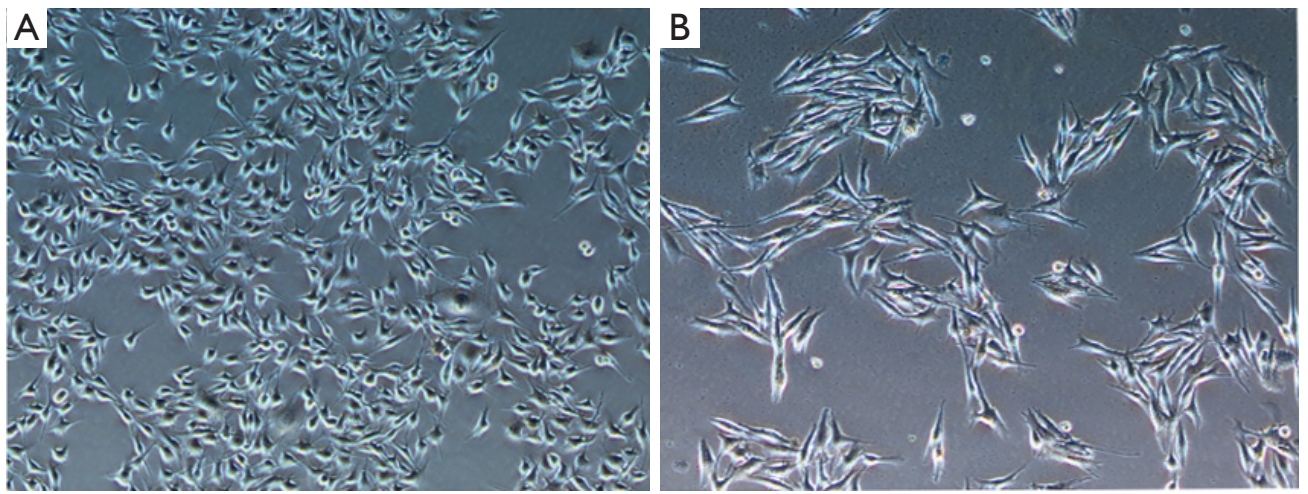

Figure 2 Changes in the morphology of the B16F10 cells treated with $60 \mu \mathrm{M}$ emodin for $24 \mathrm{~h}$ (inverted microscope, $\times 100$ ). (A) B16F10 cells in the control group grew efficiently and showed a fusiform shape. (B) After treatment with $60 \mu \mathrm{M}$ emodin, the number of B16F10 cells decreased, and the morphology of the cells began to show reticular dendritic structures. Some cell volumes decreased, and the shape became round.

the cell morphology of the B16F10 cells treated with 60 $\mu \mathrm{M}$ emodin for $24 \mathrm{~h}$ were observed under an inverted microscope (Figure 2). After treatment with $60 \mu \mathrm{M}$ emodin, the number of B16F10 cells decreased, and the morphology of the cells began to show reticular dendritic structures. Some cell volumes decreased, and the shape became round.

\section{Effect of emodin on the migration of the B16F10 cells}

After treatment of the $\mathrm{B} 16 \mathrm{~F} 10$ cells with gradient concentrations of emodin $(20,40,60$, and $80 \mu \mathrm{M})$ for 24 $\mathrm{h}$, cell migration changes were observed under an inverted microscope (Figure $3 A$ ). B16F10 cells were treated with the same gradient concentration of emodin solution for $24 \mathrm{~h}$ in the Transwell test. The number of cells migrating to the bottom surface of the membrane decreased in a concentration-dependent manner (Figure 3B). The migration ratio of the cells the experimental group was significantly reduced compared with that of the cells in the control group $(\mathrm{P}<0.05)$ (Figure $4 A)$. The number of cells migrating to the bottom surface of the membrane was significantly different from that of the control group $(\mathrm{P}<0.05)$ (Figure 4B).

\section{Effect of emodin on the apoptosis of the B16F10 cells}

Compared with those of the control group, the B16F10 cells treated with emodin at a concentration of $60 \mu \mathrm{M}$ for $24 \mathrm{~h}$ showed an increased number of fluorescently stained cells (Figure 5). Caspase-3 has an important impact on apoptosis. In our study, caspase-3 was detected and analysed by western blotting, which indicated that the expression levels of caspase- 3 had increased in cells treated with $40 \mu \mathrm{M}$ and $60 \mu \mathrm{M}$ emodin (Figure 6). These results confirmed that emodin may promote B16F10 cell apoptosis.

\section{Discussion}

The incidence of CM has been one of the most rapidly increasing among cancers worldwide. The proliferation and invasive ability of $\mathrm{CM}$ are the main factors leading to early lymphatic and distant metastasis. The poor chemotherapy effect on melanoma has led to a 5-year survival rate of patients with advanced melanoma that is still low (11). It is gratifying that with further research of melanoma performed in recent years, some advancements in targeted therapy and immunotherapy have been achieved $(12,13)$. Recently, several studies have shown that emodin can inhibit tumour growth by inhibiting tumour cell proliferation and inducing apoptosis (14-16). Emodin can also synergize with various antitumour drugs to reduce tumour resistance (17). Aloe-emodin, reported as a potential anticancer agent, has a molecular structure similar to that of emodin. Aloe-emodin can reduce tumour cell viability in a dose-dependent manner and inhibit the metastasis of tumours formed by B16F10 cells (18). The antitumour effects of emodin may similar to drugs with a similar anthraquinone structure (Figure 7). Additionally, emodin can upregulate the expression of caspase- 3 to induce the apoptosis of HeLa cells via the mitochondrial pathway 


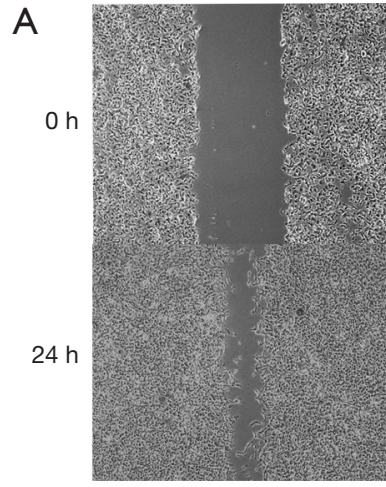

a

B

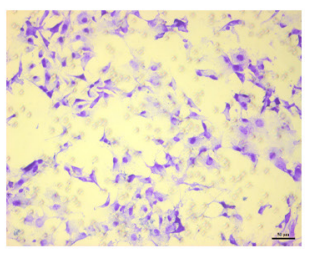

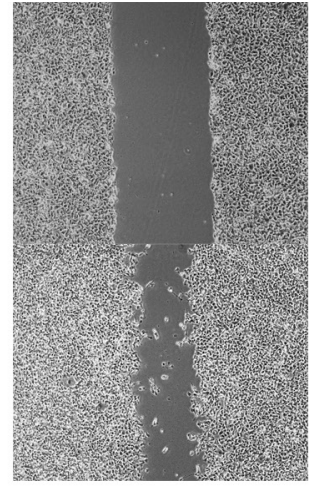

b

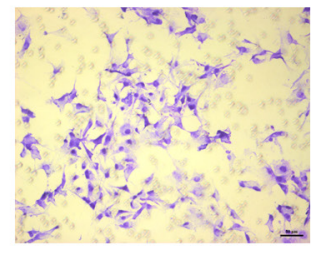

g

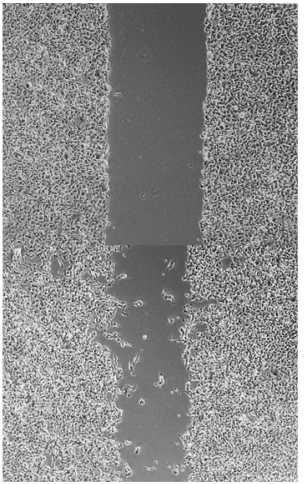

c

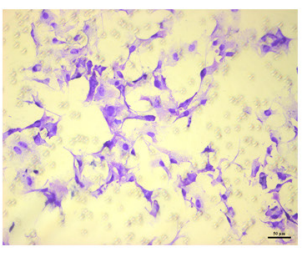

$\mathrm{h}$

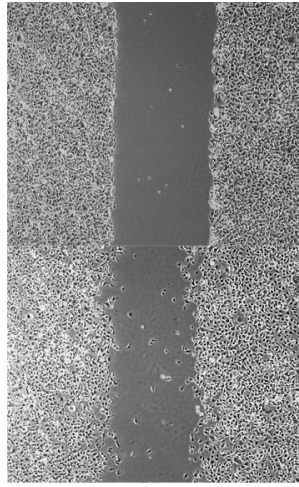

d

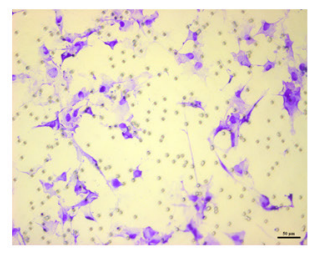

i

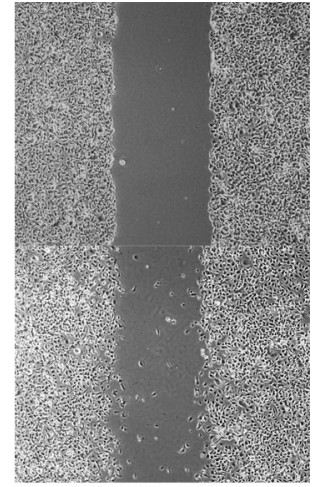

e

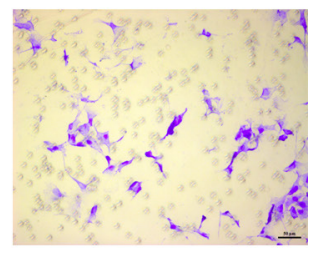

j

Figure 3 Scratch test and Transwell test of the B16F10 cells treated with different concentrations of emodin for $24 \mathrm{~h}$. (A) Cell scratch test. Panel (a) shows the control group (0.1\% DMSO). Panel (b,c,d,e) the 20, 40, 60 and $80 \mu M$ emodin groups, respectively. The cells on both sides of the scratches were uniform at $0 \mathrm{~h}$. After treatment with emodin for $24 \mathrm{~h}$, the scratch wounds in the control group monolayer had obviously healed. The scratch wounds in the cells of the $20 \mu \mathrm{M}$ emodin group also had obviously healed. The scratch wound healing in the $40 \mu \mathrm{M}$ emodin group was less obvious. The scratch wound in the $60 \mu \mathrm{M}$ emodin group showed mild healing. Scratch wound healing in the $80 \mu \mathrm{M}$ emodin group was not obvious (inverted microscope, $\times 40$ ).
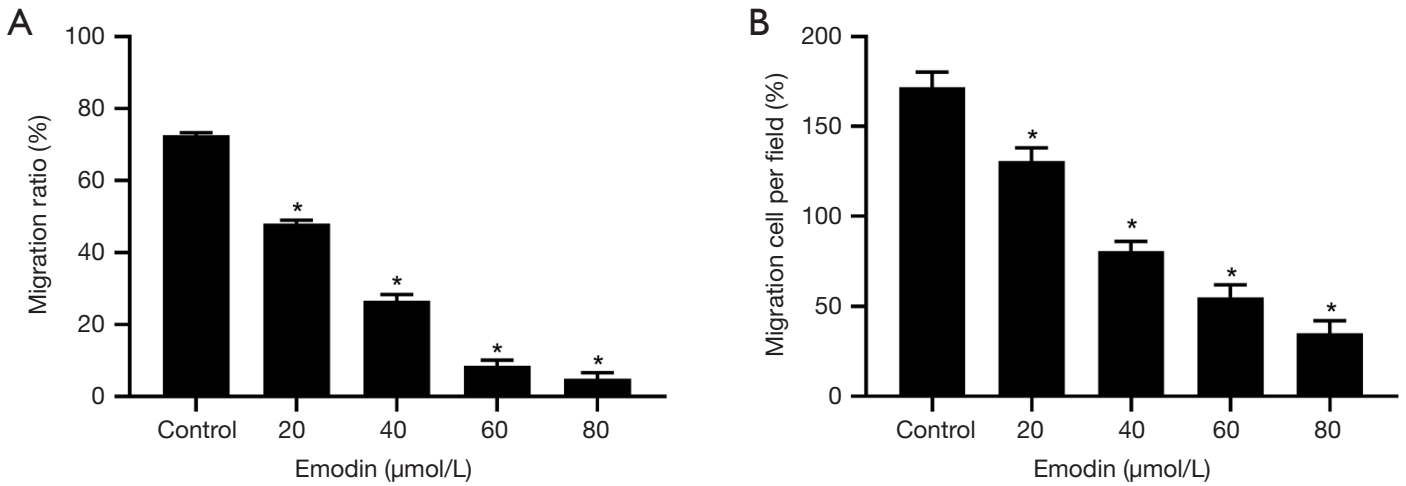

Figure 4 The migration ratio of cell scratch test and migration cells per field in the Transwell assay. (A) After $24 \mathrm{~h}$, the migration ratio of the cells in the 20, 40, 60 and $80 \mu \mathrm{M}$ emodin treatment groups was significantly reduced compared with that of the cells in the control group $\left({ }^{*}, \mathrm{P}<0.05\right)$.(B) After $24 \mathrm{~h}$, the number of cells that migrated to the bottom of the membrane in the 20, 40, 60 and $80 \mu M$ emodin treatment groups was significantly reduced compared with that of the control group $\left({ }^{*}, \mathrm{P}<0.05\right)$. 

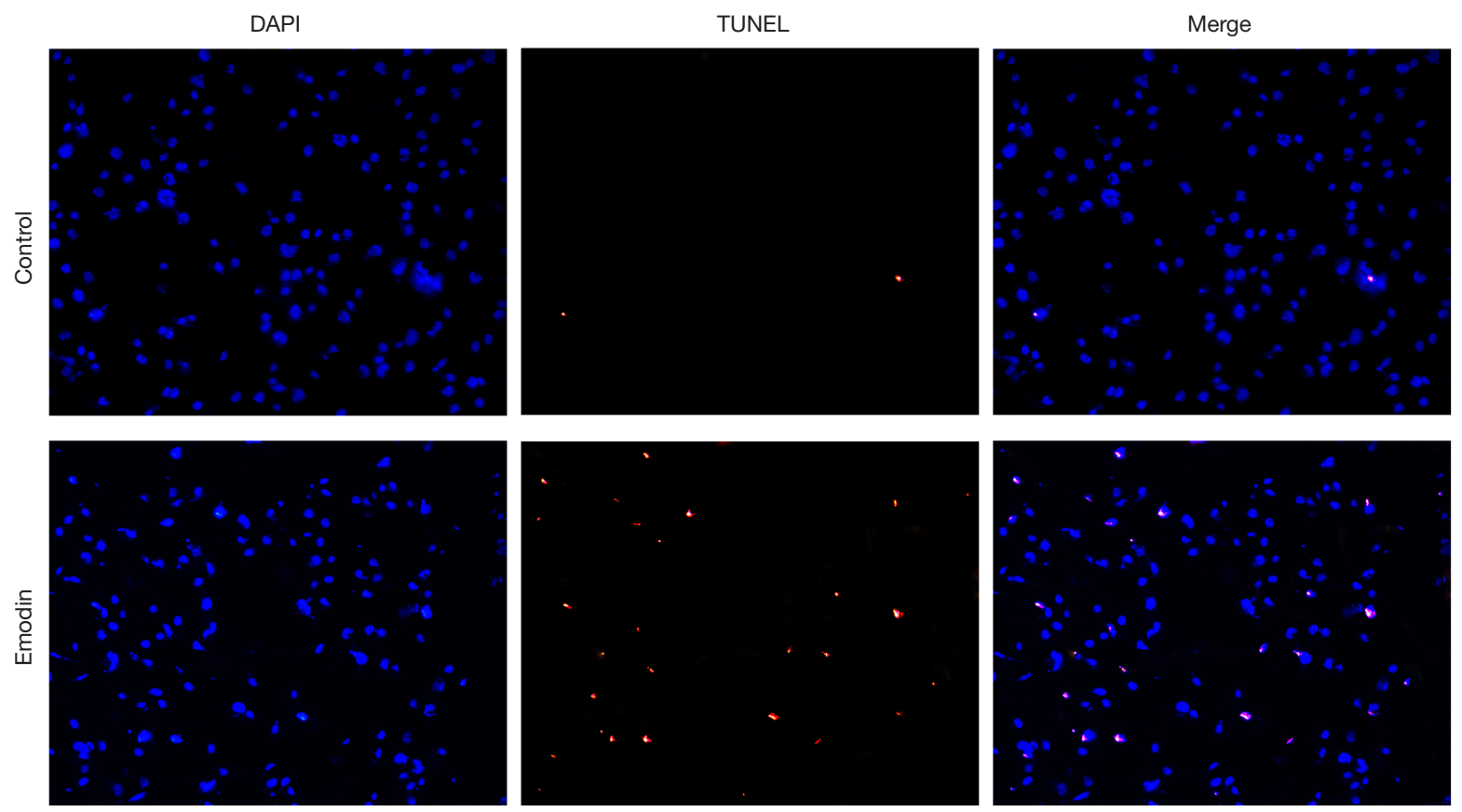

Figure 5 Fluorescence staining of B16F10 cells treated with $60 \mu \mathrm{M}$ emodin for $24 \mathrm{~h}$ (fluorescence confocal imaging microscope, $\times 100$ ). Compared with that of the control group, the number of fluorescently stained B16F10 cells was increased after treatment with emodin at a concentration of $60 \mu \mathrm{M}$ for $24 \mathrm{~h}$.

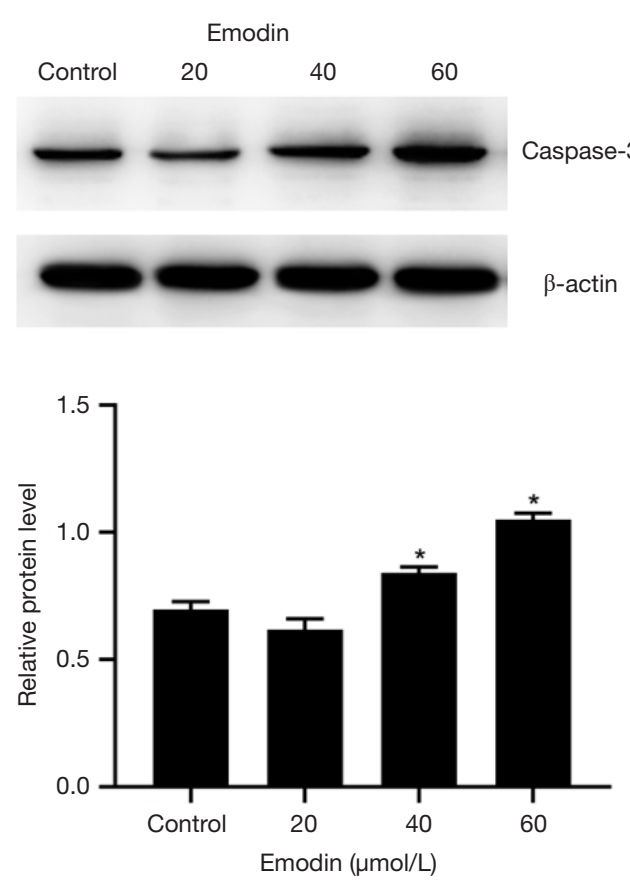

Figure 6 Western blot analysis of caspase-3. Compared with the control group, the $20 \mu \mathrm{M}$ group showed no significant difference in caspase-3 levels. The 40 and $60 \mu \mathrm{M}$ groups presented with significant differences in the expression level of caspase- 3 .

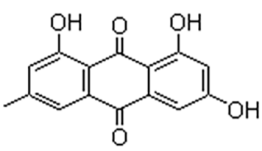

Emodin

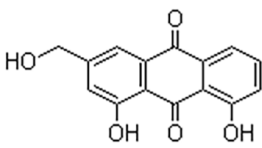

Aloe-emodin
Figure 7 Structural formulas of emodin and aloe-emodin.

and upregulate the expression of Fas and FasL to induce apoptosis through the extracellular pathway (19). Therefore, we explored the effect of emodin on B16F10 cells to provide evidence of its potential clinical application in the treatment of melanoma.

In this study, it was found that the viability of the B16 cells decreased significantly with increasing emodin concentration, indicating that emodin inhibited the proliferation of $\mathrm{B} 16 \mathrm{~F} 10$ cells in a concentration-dependent manner. The changes in the morphology of B16F10 cells treated with $60 \mu \mathrm{M}$ emodin suggest the possible induction of apoptosis. The results from the cell scratch test and Transwell test showed that emodin can significantly inhibit tumour migration. Apoptosis, also known as programmed cell death, is the basic mechanism that maintains the dynamic balance of the number of cells in the body. 
The suppression of apoptosis is an important cause of melanoma development. Apoptosis is mainly triggered by four pathways: the mitochondrial pathway, death receptormediated pathway, endoplasmic reticulum pathway and caspase-independent pathway. Caspase- 3 is a protein shared in the first two pathways. It is a key factor that executes apoptosis, making it an important protein in the process of apoptosis. The activation of the mitochondrial pathway or death receptor-mediated pathway can cause an increase in caspase-3 expression. Its expression level also reflects the extent of apoptosis. The TUNEL assay showed an increased number of fluorescently stained cells, suggesting that emodin promoted the apoptosis of the melanoma cells. Moreover, the results of the western blot analysis showed that the expression of caspase- 3 increased in the cells treated with 40 and $60 \mu \mathrm{M}$ emodin, supporting the hypothesis that emodin may cause the induction of apoptosis through the mitochondrial pathway or death receptor-mediated pathway.

\section{Conclusions}

In conclusion, the results showed that emodin effectively inhibited the proliferation of B16F10 cells, inhibited tumour cell migration and promoted cell apoptosis. Emodin may be one of the compounds for improving the therapeutic methods used for melanoma.

\section{Acknowledgments}

Funding: This work was supported by the Fund of Shanghai Science and Technology Commission (No. 19411962300) and Shanghai Municipal Health Committee (No. 201940400).

\section{Footnote}

Data Sharing Statement: Available at http://dx.doi. org/10.21037/tcr-20-1040

Peer Review File: Available at http://dx.doi.org/10.21037/ tcr-20-1040

Conflicts of Interest: All authors have completed the ICMJE uniform disclosure form (http://dx.doi.org/10.21037/tcr-201040). The authors have no conflicts of interest to declare.

Ethical Statement: The authors are accountable for all aspects of the work in ensuring that questions related to the accuracy or integrity of any part of the work are appropriately investigated and resolved.

Open Access Statement: This is an Open Access article distributed in accordance with the Creative Commons Attribution-NonCommercial-NoDerivs 4.0 International License (CC BY-NC-ND 4.0), which permits the noncommercial replication and distribution of the article with the strict proviso that no changes or edits are made and the original work is properly cited (including links to both the formal publication through the relevant DOI and the license). See: https://creativecommons.org/licenses/by-nc-nd/4.0/.

\section{References}

1. Lee C, Collichio F, Ollila D, et al. Historical review of melanoma treatment and outcomes. Clin Dermatol 2013;31:141-7.

2. Nikolaou V, Stratigos AJ. Emerging trends in the epidemiology of melanoma. Br J Dermatol 2014;170:11-9.

3. Ferlay J, Steliarova-Foucher E, Lortet-Tieulent J, et al. Cancer incidence and mortality patterns in Europe: estimates for 40 countries in 2012. Eur J Cancer 2013;49:1374-403.

4. Bradford PT, Anderson WF, Purdue MP, et al. Rising melanoma incidence rates of the trunk among younger women in the United States. Cancer Epidemiol Biomarkers Prev 2010;19:2401-6.

5. Linos E, Swetter SM, Cockburn MG, et al. Increasing burden of melanoma in the United States. J Invest Dermatol 2009;129:1666-74.

6. Alisi A, Pastore A, Ceccarelli S, et al. Emodin Prevents Intrahepatic Fat Accumulation, Inflammation and Redox Status Imbalance During Diet-Induced Hepatosteatosis in Rats. Int J Mol Sci 2012;13:2276-89.

7. Lee YS, Kang OH, Choi JG, et al. Synergistic effect of emodin in combination with ampicillin or oxacillin against methicillin-resistant Staphylococcus aureus. Pharm Biol 2010;48:1285-90.

8. Lu Y, Yang JH, Li X, et al. Emodin, a naturally occurring anthraquinone derivative, suppresses IgE-mediated anaphylactic reaction and mast cell activation. Biochem Pharmacol 2011;82:1700-8.

9. Fu ZY, Han JX, Huang HY. Effects of emodin on gene expression profile in small cell lung cancer NCI-H446 cells. Chin Med J (Engl) 2007;120:1710-5.

10. Li WY, Chan RY, Yu PH, et al. Emodin induces cytotoxic 
effect in human breast carcinoma MCF-7 cell through modulating the expression of apoptosis-related genes. Pharm Biol 2013;51:1175-81.

11. Williams GH, Stoeber K. The cell cycle and cancer. J Pathol 2012;226:352-64.

12. Weber J, Mandala M, Del Vecchio M, et al. Adjuvant Nivolumab versus Ipilimumab in Resected Stage III or IV Melanoma. N Engl J Med 2017;377:1824-35.

13. Maio M, Lewis K, Demidov L, et al. Adjuvant vemurafenib in resected, BRAF(V600) mutation-positive melanoma (BRIM8): a randomised, double-blind, placebo-controlled, multicentre, phase 3 trial. Lancet Oncol 2018;19:510-20.

14. Huang Q, Lu G, Shen HM, et al. Anti-cancer properties of anthraquinones from rhubarb. Med Res Rev 2007;27:609-30.

15. Yu JQ, Bao W, Lei JC. Emodin regulates apoptotic pathway in human liver cancer cells. Phytother Res 2013;27:251-7.

Cite this article as: Yuan M, Chen L, Wang W, Qin D, Jia C, Liu C, Wang H, Zhu J, Guo Y, Zhou Y, Yang P, Zhao H, Liu T, Bi B. Emodin inhibits the proliferation and migration of B16F10 cells and induces their apoptosis. Transl Cancer Res 2020;9(10):6198-6205. doi: 10.21037/tcr-20-1040
16. Jiang J, Zhou N, Ying P, et al. Emodin promotes apoptosis of human endometrial cancer through regulating the MAPK and PI3K/ AKT pathways. Open Life Sci 2019;13:489-96.

17. Liu H, Xu H, Zhang C, et al. Emodin-Loaded PLGATPGS Nanoparticles Combined with Heparin SodiumLoaded PLGA-TPGS Nanoparticles to Enhance Chemotherapeutic Efficacy Against Liver Cancer. Pharm Res 2016;33:2828-43.

18. Tabolacci C, Lentini A, Mattioli P, et al. Antitumor properties of aloe-emodin and induction of transglutaminase 2 activity in B16-F10 melanoma cells. Life Sci 2010;87:316-24.

19. Yaoxian W, Hui Y, Yunyan Z, et al. Emodin induces apoptosis of human cervical cancer hela cells via intrinsic mitochondrial and extrinsic death receptor pathway. Cancer Cell Int 2013;13:71. 